\title{
Determinants of Mangoes and Red Peppers Market Supply in Ahferom and Kola-Tembien Districts of Tigray Region, Northern Ethiopia
}

https://doi.org/10.21272/sec.3(4).39-51.2019

Girmalem Nirea, ORCID: https://orcid.org/0000-0002-4722-2888

$\mathrm{PhD}$ Candidate, Lecturer, Department of Management, College of Business and Economics Adigrat University, Ethiopia

Negussie Semie, ORCID: https://orcid.org/0000-0002-2571-5972

$\mathrm{PhD}$, Assistant Professor, Center for Rural Development, College of Developmental Studies, Addis Ababa University, Ethiopia

Degye Goshu

$\mathrm{PhD}$, Associate Professor, Department of Economics, Kotebe Metropolitan University, Addis Ababa, Ethiopia

\begin{abstract}
The major aim of this paper was to examine the factors that determine market supply of mangoes and red peppers by smallholder growers in Ahferom and Kola-Tembien Districts of Tigray National Regional State, Northern Ethiopia. Data were collected from a sample of 192 mango growers and 191 red pepper growers. Both descriptive statistics and econometric analysis applied for analyzing the collected data. The multiple linear regression model was applied to identify the factors determining mango and red pepper market supply. The result of the descriptive analysis showed that level of mangoes and red peppers production has been raised owing to high intervention and follow up of the regional government on the sector through increasing level of accountability and building competitive sprite among agricultural extension workers. $53.6 \%$ of the sample mango growers and $27.6 \%$ of the sample red pepper growers sold their produces to retailers. The result of the estimated parameter also indicated that level of mango production, sex of the household head, household family size, access to credit and total land size were the factors that determine marketable supply of mangoes by smallholder growers. Similarly, distance to nearest market, access to market information, total land size, cooperative membership and selling price were found to be determinants of the market supply of red peppers. Finally, the study recommended intervention in appropriate distribution of inputs, improvement in rural infrastructure, promoting and expanding mango and red pepper production for export and ensuring fair trade. The current market oriented agricultural system has to be supported by mechanisms of gathering and distributing market information, appropriate crop pricing and market linkages, which enh ance market supply and improve the economic and social bargaining power of growers.
\end{abstract}

Keywords: determinant, market supply, production, smallholder growers.

JEL Classification: Q11.

Cite as: Girmalem Nirea, G., Negussie S., Degye G. (2019). Determinants of Mangoes and Red Peppers Market Supply in Ahferom and Kola-Tembien Districts of Tigray Region, Northern Ethiopia. SocioEconomic Challenges, 3(4), 39-51. https://doi.org/10.21272/sec.3(4).39-51.2019.

(C) The Authors, 2019. This article is published with open access at Sumy State University.

\section{Introduction}

Growing fruits and vegetables are crucial for smallholder farmers because it is source of both food and income. It is also advantageous for commercial growers as it is a lucrative trade activity. Albeit its advantages, it is also risky due to the perishable biological nature of the crops that gives rise to food poisoning. Besides, the production process in developing nations has characterized by poor and seasonal production usually caused by sunburn insects (Baliyan, 2014). 
Fruit and vegetable production in Ethiopia ranges from small-scale farming produced mainly for household consumption to large-scale production for local, regional and international markets (Adugna, 2009). At national level, 139,717.15 hectare of land was covered by vegetables like lettuce, head cabbage, Ethiopian cabbage, tomatoes, green peppers, red peppers, and Swiss chard producing 5,954,004.03 quintals of crops and $90,070.83$ hectare of land was covered by fruits such as avocadoes, bananas, guavas, lemons, mangoes, oranges, papayas and pineapples producing 7,066,485.72 quintals of crops (CSA, 2015). Some studies confirmed increase in the volume of trade of fruits and vegetables in Ethiopia (Almaz et al., 2014). Nevertheless, its contribution to income and diet is still minimal (FAO and WHO, 2004).

Tigray, one of the nine National Regional States of Ethiopia, has suitable climate for production of different fruits such as bananas, guavas, lemons, mangoes, oranges, papayas and avocados; as well as vegetables like lettuce, Ethiopian cabbage, head cabbage, tomatoes, green pepper, red pepper and Swiss chard (Kassa et al., 2009). A total of 937.08 hectares of land was covered by different fruits yielding $26,987.25$ quintals during the main season of the year 2014/2015. In the same period, 2,264.82 hectare of land was covered by different vegetables yielding 95,355.53 quintals (CSA, 2015). Fruits and vegetables are mainly produced for market in the Region and the production process is random and fragmented resulting in oversupply of products (Adugna, 2009). Despite this high potential, the production capacity has not been exploited adequately in the region. Fruit and vegetable productivity was 28.79 quintals per hectare and 42.1 quintals per hectare respectively during the main season of 2011/12 (CSA, 2015). This was lower than the average national productivity, which was 134.07 quintals per hectare for fruits and 192 quintals per hectare for vegetables during the same year (EIA, 2012). This paper presents the factors that affect market supply of mangoes and red peppers in Ahferom and Kola-Tembien districts of Tigray Region.

\section{Literature review}

Supply chain is the flow of goods from suppliers to final consumers and it focuses on logistical and procedural activities involved during production of final products (Abraham, 2013). It focuses on cost and efficiencies of supply of commodities and creating integrated relationship between supplier and producer (Liliana-Adina, 2012). According to Kotler and Keller (2006), performing well in market supply is the result of careful planning and implementation. There is a need to coordinate the linkage between producers and markets (Tamasese, 2009).

However, the supply value chains of developing countries is constrained by many difficulties. According to Bezabih (2008), lack of markets to absorb the production, low price for the products, large number of middlemen in the marketing system, lack of marketing institutions safeguarding farmers' interest and rights over their marketable products such as cooperatives, lack of coordination among producers to increase their bargaining power, poor product handling and packaging, imperfect pricing system, lack of transparency in market information system mainly in the export market were the major constraints during marketing horticulture crops in Kombolcha district of Eastern Oromia, Ethiopia. Similarly, Baloyi (2010) identified major constraints facing smallholder fruit and vegetable growers in developing countries, which are discussed below.

\section{1) Production Constraints.}

Developing countries have poor access to common production resources (land, labor force, capital and entrepreneurship). This results in low volume of production and quality, which affects in turn the way smallholder growers can benefit from market supply of fruits and vegetables.

\section{2) Poor Quality and Low Quantity of Produces.}

Smallholder growers produce low quality crops as they have little knowhow on production techniques and due to low level of farming infrastructures. Additionally, there is low level of production due to shortages in the so called production factors resulting in low amounts of market supply of crops.

\section{3) Absence of Infrastructures and Little Bargaining Power.}

Smallholder growers in developing countries lack access to infrastructure like cold storage, market information and transportation. Lack of cold storage facility leads to spoilage of crops constituting entry barrier into profitable markets. Likewise, growers seldom obtain accurate information on market demand, 
price, quality requirement and potential buyers. This affects trading capability and profitability. Besides, lack of access to modern transportation facilities results in late delivery of products reducing selling price.

\section{4) Shortage of Human Capital.}

Majority of the smallholder growers in developing countries have low access to education and they have little technical, marketing and financial skills. This narrows the opportunity of meeting quality standards set by local and international fruit and vegetable markets as well as processing industries.

\section{5) High Transaction Costs.}

Transaction costs include information, monitoring, negotiation, coordination, and contract enforcement costs. These costs are very high for smallholder growers due to absence of formal markets, information inefficiencies and institutional problems.

\section{6) Inconsistency in Production.}

Naturally, fruit and vegetable supply is seasonal. For this reason, smallholder growers cannot supply their produces continuously into the local, national, regional and international markets.

\section{7) Lack of Surrounding Markets.}

Most smallholder growers are located at rural areas where there is no or very little access to market. Usually, they sold their produces in the local market at relatively lower cost or transport them into towns at higher transportation costs. This lowers the profit margin of smallholder growers. Besides, there are regulatory barriers like high quality products, knowledge of GAP (Good Agricultural Practices) and SPS (Sanitary and Phytosanitary) measures and technological barriers, which prohibit smallholder growers to position themselves as global market competitors. Likewise, fruit and vegetable marketing trend in Ethiopia is constrained by inefficiency in production and imperfect competition in the market (Adugna, 2009).

\section{Methodology and research methods}

The multiple-linear regression model was applied to analyze the factors that determine market supply of fruits and vegetables by smallholder growers. Any dependent variable depends on the vector of explanatory variables and the disturbance term. Hence, the multiple-linear regression model proposed here was:

$Y=\beta X^{\prime}+U$

Where: $Y=$ quantity of fruits or vegetables supplied to market, $X^{\prime}=$ the vector of the explanatory variables, $\beta$ $=$ the parameters to be estimated, $U=$ disturbance term.

According to Gujarati (2004), any scientific study has certain assumptions that might not be necessarily realistic but replicate reality exactly. Hence, it is important enough to warrant valid specification of the multiple-linear regression model in consistent with the CLRM assumptions. Accordingly, appropriate tests of multicollinearity, endogeneity and heteroscedasticity has been performed to assure the assumptions of Classical Linear Regression Model (CLRM) are not violated and the parameter estimation is Best Linear Unbiased Estimator (BEST).

The multicollinearity problem exists whenever there is correlation among two or more explanatory variables, which makes it challenging to detect the specific effect of explanatory variables on the dependent variable, keeping other factors constant (Gujarati, 2004). It was tested using the variance-inflation factor (VIF). The conventional rule of thumb is that multicollinearity problem exists when the result of VIF is above 10. Studies conducted by Abraham (2013), Addisu (2016) and Bekele et al. (2017) have applied this threshold. For this study, all VIF results were less than 10 with mean value of 1.26 for mango and 1.34 for red pepper (Appendix A). Therefore, there is not multicollinearity problem within the explanatory variables.

The problem of endogeneity occurs when there is a non-zero correlation among the explanatory variables and the disturbance term. The major causes of endogeneity (also known as simultaneity) are omitted variables and measurement error (Ajmani, 2009). Essentially, the Ordinary Least Square (OLS) estimation method is consistent when all explanatory variables are exogenous. Under the situation that at least one explanatory variable is endogenous, OLS is inconsistent and the Instrumental Variable (IV) method should be applied instead (Chmelarova, 2007). The Hausman specification test and Durbin-Wu-Hausman (DWH) test can be 
used to test endogeneity. The null hypothesis under the Hausman specification test for endogeneity is that there should not be considerable difference among the coefficients of the parameters estimated by OLS and IV estimators. If there is slight difference between the parameters, then all explanatory variables are exogenous and OLS is consistent. If the difference is considerable, then the suspected variable is endogenous and the parameter estimation should be done using IV estimator method (Cameron and Trivedi, 2009). The DWH test comprises two regressions. In the first regression, the suspected endogenous variable $\left(\mathrm{Y}_{\mathrm{i}}\right)$ is taken as dependent variable and the exogenous (X) and instrument variables (Z) are taken as independent variables. Then, the residuals will be saved. In the second regression, the dependent variable (Y) will be regressed with the exogenous variables $(\mathrm{X})$, the endogenous variable $\left(\mathrm{Y}_{\mathrm{i}}\right)$ and the residuals. If the effect of the residuals is significant, then there is endogeneity (Stock and Watson, 2011).

In this study, the DWH test was applied to test endogeneity. The test result for both mangoes (Durbin score $\mathrm{p}$-value $=0.0153$ and Wu-Hausman $\mathrm{p}$-value $=0.0202$ ) and red peppers (Durbin score $\mathrm{p}$-value $=0.003$ and WuHausman p-value $=0.0043$ ) were significant. This indicates the existence of endogenous variable (the level of mango or red pepper production /QTY2009) in the data set. Therefore, the null hypothesis 'all variables are exogenous' has rejected and OLS was inconsistent estimator under this condition. As a result, the parameter estimation was done using the Two Stage Least Square (2SLS) estimator.

In order to assure the validity of the 2SLS estimator, both validity of instrument test (estat firststage STATA command) and over identifying restriction test (estat overid STATA command) were executed. The Fstatistics results of the validity test was 14.17 for mangoes and 16.47 for red peppers. As a rule of thumb, an F-value of less than 10 indicates the existence of weak instrumental variables. Hence, there are not weak instrumental variables in the model. The results of the over identifying restriction test also indicate a Sargan p-value of 0.6829 for mangoes and 0.7578 for red peppers. Similarly, the Basmann p-value were 0. 6973 was 0.7691 for mangoes and red peppers respectively. Therefore, the study has applied correctly specified model and valid instruments (Bekele et al., 2017).

The problem of heteroscedasticity happens when there is unequal spread of variance among explanatory variables and its presence makes t-test and F-test invalid (Gujarati, 2004). It is applied to test whether the variance of the disturbance term is dependent on the values of the explanatory variables. The Breusch-Pagan test of heteroscedasticity (developed by Trevor Breusch and Adrian Pagan in 1979) and the White test (proposed by Halbert White in 1980) can be applied to test the existence of heteroscedasticity. This study applied the Breusch-Pagan test. The procedure was the same for both mangoes and red peppers. First, the predicted value of the dependent variable (SUPPLY2009) and the error term (residual) was computed. Then, a new variable, which is the square of the residuals was generated. Finally, the explanatory variables were regressed with this new variable (square of the residuals). Lower level of significance indicates the presence of the heteroscedasticity problem. For this study, the p-value for the F-test was 0.5598 for mangoes and 0.3453 for red peppers respectively. Therefore, the null hypothesis was accepted and the model has not heteroscedasticity problem.

The market supply of mangoes and red peppers were regressed with 15 explanatory variables and one endogenous variable. Accordingly, the following econometric model was specified to analyze the factors that determine mango/red pepper supply:

$Y=\beta_{0}+\beta_{1} X_{1 i}+\beta_{2} X_{2 i}+\beta_{3} X_{3 i}+\beta_{4} X_{4 i}+\beta_{5} X_{5 i}+\beta_{6} X_{6 i}+\beta_{7} X_{7 i}+\beta_{8} X_{8 i}+\beta_{9} X_{9 i}+\beta_{10} X_{10 i}+$ $\beta_{11} X_{11 i}+\beta_{12} X_{12 i}+\beta_{13} X_{13 i}+\beta_{14} X_{14 i}+\beta_{15} X_{15 i}+\delta Y_{1 i}+U$

Where: $\mathrm{Y}=$ quantity of mangoes/red peppers supplied to market; $\mathrm{Y}_{1 \mathrm{i}}=$ level of mango/red pepper production by household-i (QTY2009); $\mathrm{X}_{1 \mathrm{i}}=$ the age of the $\mathrm{i}^{\text {th }}$ household head (AGE); $\mathrm{X}_{2 \mathrm{i}}=$ the sex of the $\mathrm{i}^{\text {th }}$ household head (SEX); $\mathrm{X}_{3 \mathrm{i}}=$ the level of education of the $\mathrm{i}^{\text {th }}$ household head (EDUC); $\mathrm{X}_{4 \mathrm{i}}=$ the $\mathrm{i}^{\text {th }}$ household family size (HHFS); $\mathrm{X}_{5 \mathrm{i}}=$ distance from $\mathrm{i}^{\text {th }}$ household to nearest market (DNM); $\mathrm{X}_{6 \mathrm{i}}=$ access to market information by household-i (INFO); $\mathrm{X}_{7 \mathrm{i}}=$ access to credit by household-i (ACR); $\mathrm{X}_{8 \mathrm{i}}=$ access to agricultural extension services by household-i (EXSERV); $\mathrm{X}_{9 \mathrm{i}}=$ land size of household-i covered by mangoes/red peppers (LVFSIZE); $\mathrm{X}_{10 \mathrm{i}}$ $=$ cost of transportation paid by household-i (TRANS); $\mathrm{X}_{11 \mathrm{i}}=$ off-farm income by household-i $(\mathrm{OFI}) ; \mathrm{X}_{12 \mathrm{i}}=$ mango/red pepper crops growing experience of household-i (EXP); $\mathrm{X}_{13 \mathrm{i}}=$ size of livestock owned by household-i (SLS); $\mathrm{X}_{14 \mathrm{i}}=$ household-i cooperative membership (MCO); $\mathrm{X}_{15 \mathrm{i}}=$ selling price of mango/red pepper of household-i at farm gate (SP2009); $\beta_{0}, \beta_{1}-\beta_{16} \&$ and $\delta=$ the parameters to be estimated; $\mathrm{U}=$ disturbance term. 
Similarly, the following econometrics model was specified for mango/red pepper production level to be run in the first stage regression of 2SLS:

$Y_{1 i}=\alpha_{0}+\alpha_{1} X_{1 i}+\alpha_{2} X_{2 i}+\alpha_{3} X_{3 i}+\alpha_{4} X_{4 i}+\alpha_{5} X_{5 i}+\alpha_{6} X_{6 i}+\alpha_{7} X_{7 i}+\alpha_{8} X_{8 i}+\alpha_{9} X_{9 i}+\alpha_{10} X_{10 i}+$

$\alpha_{11} X_{11 i}+\alpha_{12} X_{12 i}+\alpha_{13} X_{13 i}+\alpha_{14} X_{14 i}+\alpha_{15} X_{15 i}+\alpha_{16} I V_{1}+\alpha_{17} I V_{2}+V$

Where: $\alpha_{0}, \alpha_{1}-\alpha_{17}=$ the parameters to be estimated; $I V_{1} \& I V_{2}=$ the two instrumental variables (FERTDAP and FERTUREA).

\section{Expected Signs of Independent Variables}

The continuous dependent variable was market supply of mangoes red peppers measured in kilograms and denoted as Y. It signifies the actual amount of mangoes/red peppers supplied into the market. The expected signs of the explanatory variables have depicted in the following table.

Table 1. Variables definition and working hypotheses for Market Supply factors

\begin{tabular}{|l|l|l|c|}
\hline Variable Definition & Symbol & Variable Type & Expected Sign \\
\hline HH head age & AGE & Continuous (years) & $(-)$ \\
\hline HH head sex & SEX & Dummy (1=M, 2=F) & $(+)$ \\
\hline HH head education level & EDUC & Continuous (educ. level) & $(+)$ \\
\hline HH family size & HHFS & Continuous (number) & $(+)$ \\
\hline Distance to nearest market & DPNM & Continuous (kilometer) & $(-)$ \\
\hline Access to mkt. information & INFO & Dummy (1=yes, 0=no) & $(+)$ \\
\hline Access to credit & ACR & Dummy (1=yes, 0=no) & $(+)$ \\
\hline Access to extension services & EXSERV & Dummy (1=yes, 0=no) & $(+)$ \\
\hline Land size & LVFSIZE & Continuous (M $\left.{ }^{2}\right)$ & $(+)$ \\
\hline Off-farm income & OFI & Continuous (Birr) & $(+)$ \\
\hline Crop growing experience & EXP & Continuous (years) & $(+)$ \\
\hline Size of livestock & SLS & Continuous (number) & $(+)$ \\
\hline Cooperative membership & MCO & Dummy (1=yes, 0=no) & $(+)$ \\
\hline Level of production & QTY2009 & Continuous (kilogram) & $(+)$ \\
\hline Cost of transportation & TRANS & Continuous (Birr) & $(-)$ \\
\hline Selling price & SP2009 & Continuous (Birr) & $(+)$ \\
\hline
\end{tabular}

Source: Own hypothesis based on reviewed literature.

\section{Results}

\section{Mango and Red Pepper Production and Supply Trends}

The production level of mango and red pepper has been expanding in terms of quantity and number of growers. Mango production has increased from 120.14 quintals in 2012/13 to 782.02 quintals in 2016/17 and red pepper production has increased from 613.6 to 1614.42 quintals during the same period. Similarly, number of mango growers has increased from 2426 in 2015/16 to 4354 in 2016/17. During the same period, the number of red pepper growers has increased from 3852 to 4331 . Accordingly, supply of these crops was also raised. Figures 1 and 2 depict the supply trends of mangoes and red peppers respectively.

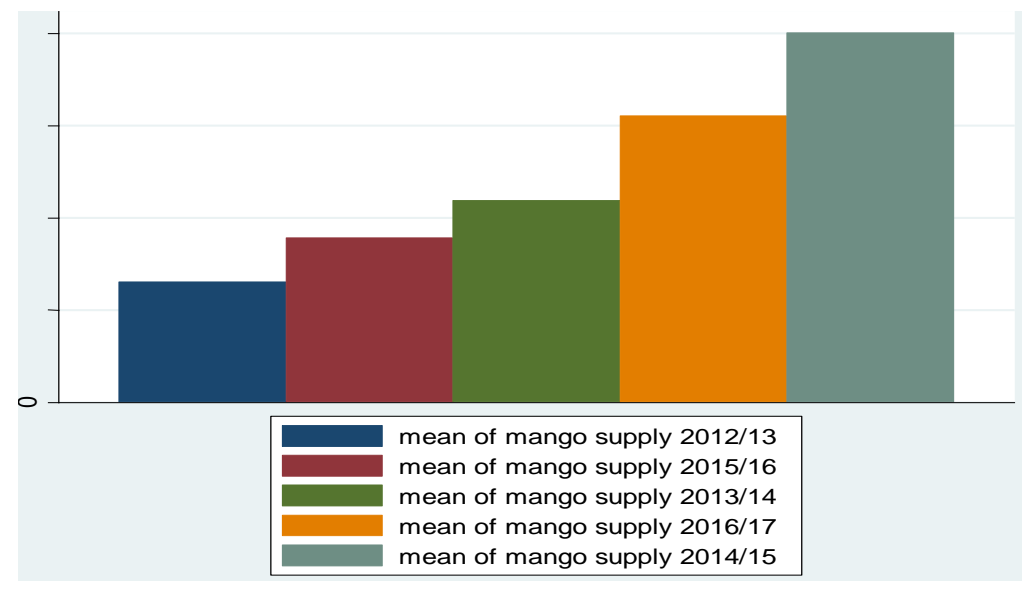

Figure 1. Level of Mango supply during the specified periods

Source: Own sketch based on survey data. 
The largest portion of mangoes (39.08\%) was supplied during 2016/17 followed by $25.9 \%, 17.64 \%, 11.43 \%$ and 5.96\% in 2015/16, 2014/15, 2013/14 and 2012/13 respectively (Figure 1). So, the level of mango supply has increased in the last five years. This was due to increase in production and demand of the crop. This is in contrast with Takele et al. (2017) who found that lack of market that observe high product was one constraint of mango marketing in Ethiopia. Similarly, market supply of red pepper has found to be increased in the last five years. Much of red peppers were supplied during the year 2016/17 (31.43\%) followed by 2015/16 (23.61\%), 2014/15 (18.8\%), 2013/14 (13.16\%) and 2012/13 (13\%) (Figure 2).

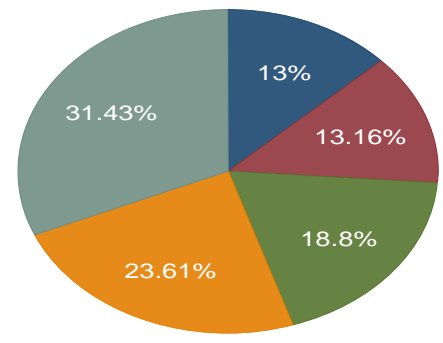

2012/13 red pepper sale amount (in kilogram) 2013/14 red pepper sale amount (in kilogram) 2014/15 red pepper sale amount (in kilogram)

2015/16 red pepper sale amount (in kilogram)

2016/17 red pepper sale amount (in kilogram)

Figure 2. Level of Red pepper supply during the specified periods

Source: Own sketch based on survey data.

\section{Factors that Affect Mango Production}

2SLS was run using 15 explanatory variables, one endogenous variable and two instrumental variables (FERTDAP2009 and FERTUREA2009) to determine factors that affect volume of mango and red pepper supply to the market. Parameter estimators might be contaminated either by outliers or influential observations. Robust regression can be applied as an alternative to the estimators as it detects outliers and influential observations and minimize their impact on the coefficient estimates (Rousseeuw and Leroy, 1987). Hence, 2SLS estimate result have done using robust regression. Table 2 presented the factors that affect mango production in Ahferom district. The overall model was statistically significant at 0.0019 level indicating the goodness-of-fit of the model in explaining the relationship of the hypothesized variables at $95 \%$ confidence level. The result for the coefficient of multiple determinations $\left(\mathrm{R}^{2}\right)$ indicates that $28.7 \%$ of the variance in dependent variable (mango production) was explained by the variables included in the model.

Table 2. Factors affecting mango production

\begin{tabular}{|c|c|c|c|c|}
\hline Production level & Coefficient & Robust Std. Err. & t-value & $\mathrm{P}>|\mathrm{t}|$ \\
\hline HH head age & 1.562532 & 3.247686 & 0.48 & 0.631 \\
\hline HH head sex & -62.17172 & 86.98698 & -0.71 & 0.476 \\
\hline HH head education level & 24.46533 & 31.49442 & 0.78 & 0.438 \\
\hline HH family size & 44.02788 & 27.6871 & 1.59 & 0.114 \\
\hline Distance to nearest market & -18.75241 & 36.78217 & -0.51 & 0.611 \\
\hline Information access & 108.7865 & 94.85536 & 1.15 & 0.253 \\
\hline Credit access & -103.5289 & 100.6841 & -1.03 & 0.305 \\
\hline Extension service & -118.6592 & 150.8161 & -0.79 & 0.432 \\
\hline Transportation cost & 3.551782 & 2.185915 & 1.62 & 0.106 \\
\hline Land size & $.229012^{*}$ & .1285109 & 1.78 & 0.076 \\
\hline Off-farm income & 42.28825 & 93.61692 & 0.45 & 0.652 \\
\hline Experience & 10.81943 & 14.34863 & 0.75 & 0.452 \\
\hline Size of livestock & $\mathbf{7 . 5 3 7 8 3 7 *}^{*}$ & 4.346632 & 1.73 & 0.085 \\
\hline Member of cooperative & 12.76028 & 128.6188 & 0.10 & 0.921 \\
\hline Selling price & -3.819495 & 8.313528 & -0.46 & 0.646 \\
\hline Dap utilization ${ }^{\text {IV }}$ & $6.072494^{* * * *}$ & 2.294937 & 2.65 & 0.009 \\
\hline Urea utilization ${ }^{\text {IV }}$ & .4064131 & 1.480433 & 0.27 & 0.784 \\
\hline cons & -301.1786 & 360.9518 & -0.83 & 0.405 \\
\hline No. of observations & 192 & & & \\
\hline Prob $>\mathrm{F}$ & $0.0019^{* * * *}$ & & & \\
\hline R-squared & 0.2871 & & & \\
\hline
\end{tabular}

Note that $* * *, * *$ and $*$ indicate significance levels at $1 \%, 5 \%$ and $10 \%$ respectively.

Source: Own computation based on survey data (2017/18). 


\section{Determinants of Market Supply of Mango}

The second stage regression of 2SLS detected the factors that determine marketable mango supply by smallholder growers (Table 3). Accordingly, level of mango production (QTY2009), sex of the household head (SEX), household family size (HHFS), access to credit (ACR) and land size (LVFSIZE) have significant effect on the market supply of mangoes. The other assumed explanatory variables were insignificant. The overall p-value (Prob > F =0.0000) specifies the goodness-of-fit of the model in explaining the relationship between mango supply and the explanatory variables.

Level of Mango Production (QTY2009): As expected, this variable had a positive sign and was significant at less than $1 \%$ level. The coefficient this variable implies an increase in the production level of mango by one kilogram per square meter resulted in an increase in farm level marketed supply of the crop by 0.5 kilogram, keeping other variables constant. The reason behind this is growers sell more if there is extra production. Besides, mangoes should be sold fast after harvest as they are perishable in nature. This is similar to the findings of previous studies. Berhanu (2012) and Elias et al. (2016) found an increase in the amount of milk yield by one litter results in an increase in the supply of milk by 0.162 and 0.4067 litters respectively at $1 \%$ level of significance for both. Addisu (2016) also investigated that there was positive and significant relation between potato productivity and potato market supply at $1 \%$ level of probability.

Table 3. Determinants of mango supply to the market

\begin{tabular}{|c|c|c|c|c|}
\hline Market supply & Coefficients & Robust Std. Err. & z-value & $\mathrm{P}>|\mathrm{z}|$ \\
\hline Production level & $5018614^{* * *}$ & .1834397 & 2.74 & 0.006 \\
\hline HH head age & -1.803428 & 2.491768 & -0.72 & 0.469 \\
\hline HH head sex & 158.1229** $^{* *}$ & 77.8934 & 2.03 & 0.042 \\
\hline HH head education level & -.7004096 & 18.48398 & -0.04 & 0.970 \\
\hline HH family size & $\mathbf{4 4 . 4 7 3 3 7}^{* * *}$ & 18.29005 & 2.43 & 0.015 \\
\hline Distance to nearest market & -19.8503 & 34.60839 & -0.57 & 0.566 \\
\hline Information access & -34.0919 & 78.17826 & -0.44 & 0.663 \\
\hline Credit access & $-150.8912^{* * *}$ & 71.7978 & -2.10 & 0.036 \\
\hline Extension service & 42.58452 & 79.56935 & 0.54 & 0.593 \\
\hline Transportation cost & 1.770907 & 2.019085 & 0.88 & 0.380 \\
\hline Land size & $.3589298^{* *}$ & .1741735 & 2.06 & 0.039 \\
\hline Off-farm income & 62.44222 & 66.85034 & 0.93 & 0.350 \\
\hline Experience & -7.769371 & 9.371884 & -0.83 & 0.407 \\
\hline Size of livestock & 1.227464 & 2.345849 & 0.52 & 0.601 \\
\hline Member of cooperative & 91.89902 & 84.30704 & 1.09 & 0.276 \\
\hline Selling price & -5.971893 & 6.454058 & -0.93 & 0.355 \\
\hline cons & -186.4861 & 226.3456 & -0.82 & 0.410 \\
\hline No. of observations & 192 & & & \\
\hline Prob $>F=$ & $0.0000^{* * * *}$ & & & \\
\hline R-squared = & 0.6113 & & & \\
\hline
\end{tabular}

Source: Own computation based on survey data (2017/18).

Sex of the Household Head (SEX): As expected, household head sex affected the market supply of mango positively at less than 5\% level of significance. This justifies smallholder growers with male household heads supply more mango to market than female headed growers. Specifically, being male headed household increases the market supply of mango by 158 kilograms than being female headed household. Usually, women rent full or portion of their land for money or half share during the harvest period due to overlapped household activities. Consequently, they collect and supply lesser amount of the crops than their male counterparts. This is consistent to Almaz et al. (2014), who found that male headed households have high family labor, better social organization, better extension contact and better farming experience than their female counterparts. Similarly, Fayera, et al. (2017) investigated that sex of the household head affected market supply bamboo poles positively and significantly.

Household Family Size (HHFS): As hypothesized, this variable related with the market supply of mango positively and significantly at less than $5 \%$ level of significance. Particularly, marketable mangoes increase by 44.5 kilogram as family size increases by one man equivalent. This is in line with previous studies. Nga et al. (2012) found that households with larger family size in the adult equivalent supply higher amount of milk than 
households with smaller family size. Similarly, Almaz et al. (2014) explored that households with larger family size in the adult equivalent own better labor, had higher produces and supply more vegetables to the market.

Access to Credit (ACR): Surprisingly, this variable had significant and negative relation with the quantity of mango supplied to the market at less than 5\% significance level. This is opposite to what was hypothesized. The coefficient of this variable indicates having access to credit decreases market supply of mango by 150.8 kilogram. The reasons behind could be majority of the sample growers use the credit for activities other than growing mangoes such as buying livestock other than oxen $(65.6 \%)$, starting trade $(16.2 \%)$ and building house $(13.5 \%)$.

Land Size Covered by Mangoes (LVFSIZE): As anticipated this variable had positive and significant relation with marketable supply of mango $10 \%$ level of significance. As the size of land covered by mangoes increased by one meter square, the amount of mango supplied to the market increased by 0.36 kilograms. Corresponding to this, Mebrat (2014) observed that the market supply of tomato increased with the land size allocated for that crop. Likewise, Habtamu (2015) found that growers with larger size of cultivable land produce more volumes of potato that ensured marketed surpluses.

\section{Factors that Affect Red Pepper Production}

The factors that affect red pepper production are presented in Table 4 below. The econometric model was statistically significant $(\mathrm{p}=0.0000)$ which specifies the goodness-of-fit of the model. The result for the coefficient of multiple determinations $\left(\mathrm{R}^{2}\right)$ implies that $38.9 \%$ of the variance in red pepper production was explained by the variables included in the model.

The first stage regression of 2SLS result indicated household head age (AGE), utilization of urea (FERTUREA2009) and selling price (SP2009) were the three predictors of red pepper production. Household head age had a positive and significant relation with red pepper production nearly at $10 \%$ level of significance. This was the expected sign and similar with the finding of Nga et al. (2012), who found positive and significant relation between household head age and market participation decision of milk producers. Almaz et al. (2014) also found that as the age of growers increased, they developed more experience and knowledge and allocate more size of land to vegetable production.

Similarly, utilization of urea affected red pepper production positively at less than $1 \%$ level of significance. It is obvious that proper utilization of fertilizers raise volume of agricultural production. Previous studies confirmed the same result. Addisu (2016) found that the amount of fertilizer application influenced potato and onion productivity positively and significantly.

Table 4. Factors affecting red pepper production

\begin{tabular}{|c|c|c|c|c|}
\hline Production level & Coefficients & Robust Std. Err. & t-value & $\mathrm{P}>|\mathrm{t}|$ \\
\hline HH head age & $15.44261^{*}$ & 9.161407 & 1.69 & 0.094 \\
\hline HH head sex & -161.28 & 126.607 & -1.27 & 0.204 \\
\hline HH head education level & -19.04146 & 45.01886 & -0.42 & 0.673 \\
\hline HH family size & -62.24292 & 42.17161 & -1.48 & 0.142 \\
\hline Distance to nearest market & 13.80904 & 59.31165 & 0.23 & 0.816 \\
\hline Information access & -172.5816 & 158.4724 & -1.09 & 0.278 \\
\hline Credit access & 52.60703 & 115.3248 & 0.46 & 0.649 \\
\hline Extension service & 52.29285 & 142.109 & 0.37 & 0.713 \\
\hline Transportation cost & 3.281285 & 7.672642 & 0.43 & 0.669 \\
\hline Land size & .0250546 & .017517 & 1.43 & 0.154 \\
\hline Off-farm income & 28.19808 & 113.6162 & 0.25 & 0.804 \\
\hline Experience & 15.47596 & 26.53709 & 0.58 & 0.561 \\
\hline Size of livestock & -.4085482 & 3.241394 & -0.13 & 0.900 \\
\hline Member of cooperative & 109.0634 & 119.7608 & 0.91 & 0.364 \\
\hline Selling price & $-23.81953^{*}$ & 14.41287 & -1.65 & 0.100 \\
\hline Dap utilization IV & .3527256 & .3471155 & 1.02 & 0.311 \\
\hline Urea utilization IV & $5.929772^{* * * *}$ & 1.069956 & 5.54 & 0.000 \\
\hline ccons & 641.1065 & 569.5346 & 1.13 & 0.262 \\
\hline No. of observations & 191 & & & \\
\hline Prob $>F=$ & $0.0000^{* * * *}$ & & & \\
\hline R-squared $=$ & 0.3890 & & & \\
\hline Adj R-squared = & 0.3289 & & & \\
\hline
\end{tabular}

Source: Own computation based on survey data (2017/18). 
In opposite to expectation, selling price related with production volume of red pepper negatively at $10 \%$ significance level. Usually, producers tend to increase their products if the selling price of that product is attractive. However, this could be different for seasonal crops like red peppers. Such crops are perishable and their price declines during the harvest period when high marketable surplus existed and rises when the supply declines.

\section{Determinants of Market Supply of Red Peppers}

The second stage regression of 2SLS result for market supply of red pepper showed that distance to the nearest market (DPNM), access to market information (INFO), land size allocated for red pepper production (LVFSIZE) and cooperative membership (MCO) were found to be related positively with marketable surplus; but selling price (SP2009) had negative relation with the dependent variable at $1 \%$ level of significance. The other hypothesized variables were insignificant (Table 5).

Distance from Production to Nearby Market (DPNM): In contrary to what was expected, this variable influenced the marketable supply of red pepper positively at less than 5\% level of significance. The parameter coefficient of this variable implies level of red pepper supply increased by 125 kilograms for a kilometer increase in the market distance. This may be related with price and demand aspects. First, local markets remunerate lower price than far markets. So, growers bring their produces far for better remuneration. Second, most local residents in the study area grew red pepper for household consumption. As a result, smallholder growers should take their surpluses far from the local markets. Majority of the sample respondents (58.7\%) walk up to 5 hours to reach markets and some even walk more than 5 hours (5.7\%). This result coincides with Berhanu (2012) who observed negative and significant relation between distance to milk markets and level of milk supply. According to these authors, a kilometer away from urban center results in 0.18 liter increase in level of participation.

Table 5. Determinants of red pepper supply to the market

\begin{tabular}{|c|c|c|c|c|}
\hline Market supply & Coefficients & Robust Std. Err. & z-value & $\mathrm{P}>|\mathrm{z}|$ \\
\hline Production level & .0854459 & .1256903 & 0.68 & 0.497 \\
\hline HH head age & 4.281786 & 9.055085 & 0.47 & 0.636 \\
\hline HH head sex & -174.9784 & 109.7706 & -1.59 & 0.111 \\
\hline HH head education level & -44.77596 & 49.73461 & -0.90 & 0.368 \\
\hline HH family size & -2.088136 & 36.70867 & -0.06 & 0.955 \\
\hline Distance to nearest market & 124.9348 $^{* * *}$ & 52.08134 & 2.40 & 0.016 \\
\hline Information access & $278.5962^{* * *}$ & 121.9634 & 2.28 & 0.022 \\
\hline Credit access & -.5355543 & 98.47702 & -0.01 & 0.996 \\
\hline Extension service & -289.6567 & 227.1147 & -1.28 & 0.202 \\
\hline Transportation cost & -4.348713 & 7.209849 & -0.60 & 0.546 \\
\hline Land size & $.0453259^{* * * *}$ & .0165771 & 2.73 & 0.006 \\
\hline Off-farm income & 19.12023 & 105.8953 & 0.18 & 0.857 \\
\hline Experience & 25.13428 & 22.65647 & 1.11 & 0.267 \\
\hline Size of livestock & 1.826254 & 2.671946 & 0.68 & 0.494 \\
\hline Member of cooperative & $421.8623^{* * * *}$ & 124.9496 & 3.38 & 0.001 \\
\hline Selling price & $-36.70953^{* * * *}$ & 14.35192 & -2.56 & 0.011 \\
\hline cons & 934.0907** & 566.5005 & 1.65 & 0.099 \\
\hline No. of observations & 191 & & & \\
\hline Prob > chi2 & $0.0000^{* * * *}$ & & & \\
\hline R-squared & 0.3092 & & & \\
\hline
\end{tabular}

Source: Own computation based on survey data (2017/18).

Marketing Information (INFO): As anticipated, this variable influenced marketable surplus of red peppers positively and significantly. Smallholder growers with access to market information increase the supply level of red pepper by 278.5 kilograms. This happened because market information decreases risk aversion so that growers could bring their crops confidently. Previous studies on similar issue attained the same findings. Abraham (2013) found that the marketable supply of potato and tomato increased if growers get market information. Similarly, Mesfin and Babu (2018) found that producers having sesame related market information raise the quantity of marketable sesame supply by 0.26 quintal.

Land Size Allocated for Red Pepper Production (LVFSIZE): This variable affected the supply of marketable red peppers positively and significantly, as it was expected. The coefficient indicated one meter square increase in the size of land covered by red peppers increased the amount of red peppers supplied to market by 0.45 kilograms. Studies conducted by Mebrat (2014) and Habtamu (2015) revealed 
positive and significant relation between volumes of tomato and potato marketed surpluses and land size respectively.

Cooperative Membership (MCO): As expected, this variable had positive and significant effect on the market supply quantity of red pepper at $1 \%$ level of significance. Being member of agricultural and/or marketing cooperatives increase the level of red pepper supply in the market by 421.9 kilograms. This is because cooperatives create marketing linkages and bargaining power to their members enabling them to supply more produces into the market. This result has well supported by Bizualem et al. (2015) who found positive and significant relation between being member of coffee cooperatives and amount of coffee supply to the market. Besides, Bekele et al. (2017) found that being a member of cooperatives increased marketed supply of potato by $18.4 \%$.

Selling Price (SP2009): Disparate to what was expected, this variable has a negative and significant relation with the quantity of market supply of red pepper at $1 \%$ level of significance. As the selling price of red pepper per kilogram increased by one Birr, then the amount of red pepper supply to the market declined by 36.7 kilograms. The negative sign is most likely related with the natural features of red peppers. Girmalem (2011) found that the perishability and seasonality natures of vegetable crops resulted in low prices during peak production periods. Likewise, Getachew et al. (2016) explained the negative relation between market supply of mushroom and its selling price by asserting that the crop had limited market options due to its perishable nature and it usually disposed at lower price during over supply.

\section{Conclusions and discussion}

This paper identified the factors determining mango and red pepper supply to various markets using 2SLS. In the first stage of the econometric analysis, determinants of mango and red pepper production were detected. Results of this analysis showed that three predictors affected mango production. These were: land size allocated to mango production, size of livestock owned by individual household and amount of dap utilized during the study period. All predictors affected the level of mango production positively and significantly. This suggested that households owning large size of land and livestock and utilizing much amount of chemical fertilizers, specially dap, tend to produce higher level of mango. Similarly, household head age, utilization of urea and selling price were three predictors of red pepper production. The first two predictors affected red pepper production positively and significantly. This indicates that experience and product enhancement mechanisms raised the level of red pepper production. Unexpectedly, the last predictor affected the production negatively and significantly. This was due to the fact that price of perishable crops declines during high marketable surplus and rises during low supply. In the second stage of the analysis, the factors affecting mango and red pepper market supply were identified. The result of the parameter showed that level of mango production, sex of the household head, household family size, access to credit and total land size were the factors that determine marketable supply of mango by smallholder growers. The result signifies smallholder mango growers tend to increase the market supply of their products as they are more experienced in production and marketing of the product and as they own more family labor and large size of land. Unlike the findings of previous studies, this study found that farmers having access to credit supply less amounts of mango to the market because they tend to participate in other trading activities. Likewise, having access to market information, owning large size of land and being member of cooperatives enabled red pepper growers to supply more products. This implies market infrastructure, production factors and supporting organizations enhance crop production and supply. Besides, distance to nearest market affected market supply of red pepper positively due to the fact that growers supply their surplus to far markets as local markets remunerate lower prices. Selling price affected the market supply decision negatively suggesting decline in price during peak supply of the product.

\section{Recommendations and policy implications}

The distribution and marketing system of agricultural inputs such as chemical fertilizers, farm equipment pesticides and herbicides is one of the issues that seeks sound policy advice. This study observed that many smallholder growers faced the difficulty of accessing adequate agricultural inputs and farm equipment due to low supply, high price and lack of good governance on the system. Besides, weak investigation on the type of soil and the consequence of applying chemical fertilizers exaggerated the 
problem to high extent. Therefore, the government is expected to improve the procurement, distribution and administration of the system as well as conduct adequate soil investigations to reduce production bottlenecks, enhance market supply of mangoes and red peppers and improve income of smallholder growers thereby ensuring rural development and economic growth.

Poor production and marketing infrastructure block agricultural development and market supply of the crops. The Ethiopian government has well designed and articulated policies and strategies advocating expansion of rural infrastructure. However, the implementation process is still minimal due to skill and budget constraints, lack of clear responsibility, bad governance and corruption. Hence, it is expected from the government to design clear, practical and participatory control mechanisms in implementing these policies and strategies. Specifically, more intervention is required by concerned governmental bodies on activities that derive competitiveness and efficiency such as modern transportation, communication, cold storage and safe packaging appliances along with offering home-to-home advisory services on how to use such appliances. Besides, the current market oriented agricultural system has to be supported by mechanisms of gathering and distributing market information, appropriate crop pricing and market linkages, which enhance market supply and improve the economic and social bargaining power of growers.

\section{Acknowledgement}

We are thankful to all contributors for this paper, especially, the fruit and vegetable experts in the offices of agriculture and rural development of Ahferom and Kola-Tembien districts, Mr. Hadush Gebrekirstos and Mr. Gebrehiwot Berhane, for their great support and cooperation during data collection process. We also appreciate those who contributed their knowledge, time, and energy to this paper. We would like to recognize the sponsorship and financial award by Ethiopian Ministry of Education and Adigrat University.

\section{List of abbreviations}

CSA - Central Statistics Agency;

EIA - Ethiopian Investment Agency;

FAO - Food and Agriculture Organization of the United Nations;

WHO - World Health Organization.

\section{References}

1. Abraham, T. W. (2013). Value chain analysis of vegetables: The case of Habro and Kombolcha Districts in Oromia Region, Ethiopia (Master's thesis). Haramaya University, Ethiopia. https://www.academia.edu/32829465/VALUE_CHAIN_ANALYSIS_OF_VEGETABLES_THE_CAS E_OF_HABRO_AND_KOMBOLCHA_WOREDAS_IN_OROMIA_REGION

2. Addisu, H. (2016). Value chain analysis of vegetables: The case of Ejere district, west Shoa zone, Oromia national regional state of Ethiopia (Master's thesis). Haramaya University, Ethiopia. https://cgspace.cgiar.org/bitstream/handle/10568/77358/thesis_addisu_2016.pdf?sequence=1\&isAllowe $\mathrm{d}=\mathrm{y}$

3. Adugna, G. T. (2009). Analysis of Fruits and Vegetables Market Chains in Alamata, Southern zone of Tigray, the Case of Onion, Tomato and Papaya (Master's thesis). Haramaya University, Ethiopia. https://pdfs.semanticscholar.org/7911/340853961adcaa422175b7b53469265513dd.pdf

4. Ajmani, V. B. (2009). Applied econometrics using the SAS system. New Jersey: John Wiley \& Sons, Inc. https://eco.cueb.edu.cn/docs/20160801190025412865.pdf

5. Almaz, G., Workneh, N., Edilegnaw, W., \& Gezahegn, A. (2014). Constraints of vegetables value chain analysis in Ethiopia: A gender perspective. International Journal of Advance Research in Management and Social Sciences, 4(12), 44-71. http://www.garph.co.uk/IJARMSS/Dec2014/6.pdf

6. Baliyan, S. P. (2014). Improving sustainable vegetable production and income through net shading: A case study of Botswana. Journal of Agriculture and Sustainability, 5 (1), 70-103. https://www.semanticscholar.org/paper/Improving-Sustainable-Vegetable-Production-and-NetBaliyan/2784829e7451706a9ab7e000f2f33009f281c868 
7. Baloyi, J. K. (2010). An analysis of constraint facing smallholder farmers in the agribusiness value chain: A case study of farmers in the Limpopo Province (Master's thesis). University of Pretoria, South Africa. https://repository.up.ac.za/handle/2263/29038

8. Bekele, W., Jema, H., \& Belaineh, L. (2017). Econometric analysis of the determinants of the quantity of potato supplied to the market: The case of Jeldu District of Oromia National Regional State, Ethiopia. Journal of Economics and Sustainable Development, 8 (13), 49-57. https://www.iiste.org/Journals/index.php/JEDS/article/view/37963

9. Berhanu, K. (2012). Market access and value chain analysis of dairy industry in Ethiopia: The case of Wolaita Zone (Doctoral Dissertation). Haramaya University, Ethiopia. https://cgspace.cgiar.org/handle/10568/24943

10. Bizualem, A., Degye, G., \& Zekarias, S. (2015). Analysis of marketed surplus of coffee by smallholder farmers in Jimma zone, Ethiopia. Journal of Biology, Agriculture and Healthcare, 5 (5), 242-251. https://pdfs.semanticscholar.org/97e5/06164b7709760e8811ba85bb0e15e647655a.pdf

11. Chmelarova, V. (2007). The Hausman test, and some alternatives, with heteroskedastic data (Doctoral Dissertation). Louisiana State University, USA. http://digitalcommons.lsu.edu/cgi/viewcontent.cgi?article=1935\&context=gradschool dissertations

12. CSA (Central Statistical Agency). (2015). Report on Area and Production of Major Crops. Addis Ababa, Ethiopia.

13. EIA (Ethiopian Investment Agency) (2012). Investment Opportunity profile for the Production of Fruits and Vegetables in Ethiopia. Retrieved January 04, 2016 from http://ethemb.se/wpcontent/uploads/2013/07/Production-of-Fruits-and-Vegetables-in-Ethiopia.pdf

14. Elias, A. G., Degefa, T., Martine, P., \& Etienne, M. (2016). Food security and nutritional impacts of smallholder farmers' participation in dairy value chain in Ethiopia. Journal of International Business and Economics, 16 (1544-8037), 21-38. https://hal.archives-ouvertes.fr/hal-02149426/

15. FAO (Food and Agriculture Organization of the United Nations \& World Health Organization). (2004). Fruits and Vegetables for Health. Report of a Joint FAO/WHO Workshop, 1 - 3 September 2004. Kobe, Japan. http://www.fao.org/3/a-y5861e.pdf

16. Fayera, B., Tsegaye, B, \& Teshale, W. (2017). Market supply determinants of lowland bamboo culms: The case of Homosha district, Northwestern Ethiopia. African journal of Marketing Management, 9(4), 46-58. https://academicjournals.org/journal/AJMM/article-full-text-pdf/F7B40D264352

17. Getachew, D., Zemedu, L., \& Eshete, A. (2016). Mushroom value chain analysis in Addis Ababa, Ethiopia. Journal of Agricultural Extension and Rural Development, 8 (8), 130-140. https://academicjournals.org/journal/JAERD/article-abstract/812185C59463

18. Girmalem, N. (2011). Identifying challenges and opportunities on the development of sustainable vegetable agro-industries in the national regional state of Tigray (Master's thesis). Mekelle University, Ethiopia. https://opendocs.ids.ac.uk/opendocs/bitstream/handle/20.500.12413/4541/Identifying\%20Challenges\%20and \%20Opportunities\%20on\%20the\%20Development\%20of.pdf.txt;jsessionid=787C99FC4F48711898F754E9 FF6B2690?sequence $=3$

19. Gujarati, D. (2004). Basic econometrics $\left(4^{\text {th }} E d\right.$.). New Delhi, India: Tata McGraw-Hill Publishing Company Limited. https://www.amazon.com/Basic-Econometrics-4th-Damodar-Gujarati/dp/0070597936

20. Habtamu, G. (2015). Analysis of potato value chain in Hadya zone of Ethiopia (Master's thesis). Haramaya University, Ethiopia. DOI: 10.33495/jeibm_v7i1.19.104

21. Kassa, A., Bauer, H., Debesey, S., Deckers, T., Alemtsehay, T., Hailay, T., Mengesha, G., Mitiku, H., Kindeya, G., \& Deckers, S. (Eds.) (2009). Tigray Fruit Forum. Proceedings of a meeting held on 3 February, 2009. Mekelle, Tigray,

Ethiopia. https://www.researchgate.net/profile/Joost_Dessein/publication/233636357_Developers_and_farmers_intert wining_interventions_The_case_of_rainwater_harvesting_and_food-forwork_in_Degua_Temben_Tigray_Ethiopia/links/Odeec530b048ca75a1000000/Developers-and-farmersintertwining-interventions-The-case-of-rainwater-harvesting-and-food-for-work-in-Degua-Temben-TigrayEthiopia.pdf

22. Katalin, J. (2012). Competitive study of the fruit and vegetable supply chain in the Netherlands (Doctoral dissertation). Szent István University, Gödöllö https://szie.hu/file/tti/archivum/Jasso_Katalin_thesis.pdf

23. Kotler, P., \& Keller, K. L. (2006). Marketing management (12 ${ }^{\text {th }}$ Ed.). USA: Pearson Education Inc. https://trove.nla.gov.au/work/4070618 
24. Liliana-Adina, N. (2012). Value chains versus supply chains. Retrieved May 16, 2016 from http://andrei.clubcisco.ro/cursuri/f/f-sym/5master/ssa-fss/Week-10\%20No14.pdf

25. Mebrat, T. (2014). Tomato value chain analysis in the central rift valley: The case of Dugda woreda, east Shoa zone, Oromia national regional state, Ethiopia (Master's thesis). Haramaya University, Ethiopia. https://www.semanticscholar.org/paper/Tomato-Value-Chain-Analysis-in-The-Central-RiftThe-Tola-Ketema/a7a4bc6a0684c108b9cb9e193b8021ab1b4e1ec8

26. Nga, B., Cuong, T., Ha L., \& Lebailly, P. (2012). Milk production and marketing in small dairy holders in the Northern area of Vietnam: A case study in Phu Dong Vietnam. Vietnam's SocioEconomic Development: A Social Science Review, 71, 57-69. https://pdfs.semanticscholar.org/4eb7/f12dbafa97d96327165d38e03513fa34352a.pdf

27. Plazibat, I., Cejvanovic, F., \& Vasiljevic, Z. (n.d.). Analysis of fruit and vegetable value chains. https://hrcak.srce.hr/index.php?show=clanak\&id clanak jezik=251894

28. POSLOVNA IZVRSNOST ZAGREB, GOD. X (2016). Retrieved July 16, 2016 from https://www.scribd.com /document/393259656/businessexcellence11022016-2

29. Rousseeuw, R. J. and Leroy, A. M. (1987). Robust Regression and Outlier Detection. New York: John Wiley \& Sons Inc. DOI: https://doi.org/10.1002/cem.1180020410

30. Stock, J. and Watson, M. (2011). Introduction to econometrics $\left(3^{\text {rd }} E d\right.$.).USA: Pearson Education Inc. https://econometricsweb.files.wordpress.com/2016/11/stock-watson-econometrics-3rd-edition-ilovepdfcompressed.pdf

31. Takele, H., Endrias, G., \& Amsalu, M. (2017). Determinants of market outlet choices of the smallholder mango producers: The case of Boloso Bombe Woreda, Wolaita zone, Southern Ethiopia. A multivariate approach. Global Journal of Science Frontier Research: D Agriculture and Veterinary, 17 (2), 23-30. https://www.semanticscholar.org/paper/Determinants-of-Market-Outlet-Choice-of-the-Mango-\%3A-HonjaGeta/ab4a36ac6d9171cd72aa1d6fe8797c1a245d2bbb

32. Tamasese, E. (2009). An Analytical Study of Selected Fruit and Vegetable Value Chains in Samoa. Food and agriculture organization of the United Nations (FAO), AAACP Paper Series No. 10. http://www.fao.org/fileadmin/templates/est/AAACP/pacific/FAO_AAACP_Paper_Series_No_10_1_.pdf

\section{Appendix A}

\begin{tabular}{|c|c|c|c|c|c|}
\hline \multicolumn{2}{|c|}{ Red pepper } & \multicolumn{3}{c|}{ Mango } \\
\hline VARIABLE & VIF & 1/VIF & VARIABLE & VIF & $1 /$ VIF \\
\hline AGE & 2.19 & 0.457157 & HHFS & 1.58 & 0.631379 \\
\hline HHFS & 1.88 & 0.530950 & AGE & 1.52 & 0.656283 \\
\hline EDUC & 1.63 & 0.614131 & DPNM & 1.43 & 0.700496 \\
\hline LVFSIZE & 1.61 & 0.621143 & EXP & 1.36 & 0.736371 \\
\hline QTY2009 & 1.37 & 0.727446 & TRANS & 1.30 & 0.771671 \\
\hline SEX & 1.29 & 0.776868 & ACR & 1.28 & 0.783257 \\
\hline TRANS & 1.20 & 0.835706 & EDUC & 1.23 & 0.811935 \\
\hline OFI & 1.19 & 0.837470 & MCO & 1.22 & 0.818373 \\
\hline DPNM & 1.19 & 0.841665 & QTY2009 & 1.21 & 0.829067 \\
\hline MCO & 1.18 & 0.848978 & LVFSIZE & 1.20 & 0.834525 \\
\hline SP2009 & 1.15 & 0.867501 & EXSERV & 1.17 & 0.851173 \\
\hline ACR & 1.12 & 0.890312 & SLS & 1.17 & 0.855852 \\
\hline EXSERV & 1.12 & 0.890608 & SEX & 1.16 & 0.863285 \\
\hline EXP & 1.12 & 0.890887 & INFO & 1.15 & 0.870974 \\
\hline INFO & 1.10 & 0.905472 & OFI & 1.06 & 0.947271 \\
\hline SLS & 1.05 & 0.956116 & SP2009 & 1.05 & 0.950079 \\
\hline Mean VIF & 1.34 & & Mean VIF & 1.26 & \\
\hline
\end{tabular}

